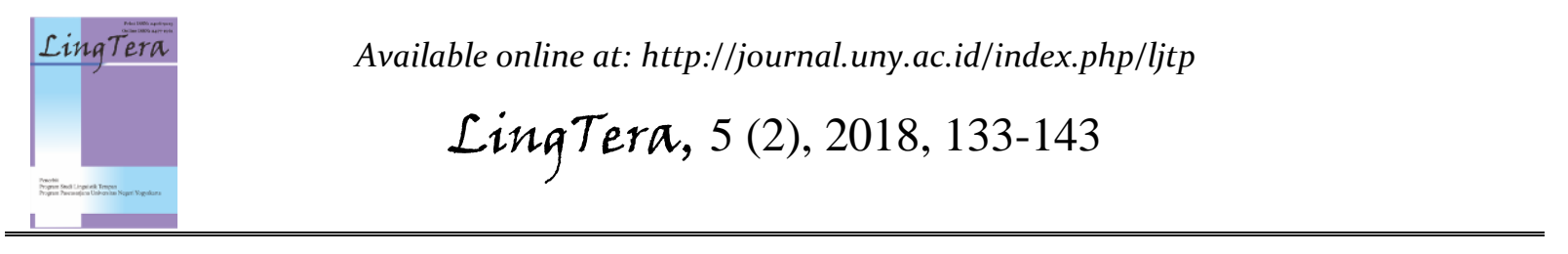

\title{
Intercultural language learning in a sister school partnership between Indonesia and Australia
}

\author{
Heni Dwi Iryanti *, Suwarsih Madya \\ Department of English Education, Graduate School, Universitas Negeri Yogyakarta. \\ Jalan Colombo No. 1, Karangmalang, Yogyakarta, 55281, Indonesia \\ * Corresponding Author. Email: heni.iryanti@gmail.com \\ Received: 23 October 2017; Revision: 6 August 2018; Accepted: 31 December 2018
}

\begin{abstract}
This case study aimed to: (1) reveal how intercultural language learning occurred within a sister school partnership in an Indonesian public high school in Yogyakarta, and (2) describe student behaviours perceived to be indicative of intercultural language learning. Using an ethnographic approach through observations and dialogues, this study investigated real life interactions occurring among the research participants within the uniqueness of the partnership between an Indonesian public high school in Yogyakarta and its Australian school partner. The results showed that intercultural language learning occurred in the forms of learning experiences which engaged the students in interaction, observation and reflection with the target community. A number of indicators of intercultural language learning were revealed in the students behaviours within four authentic language experiences including exploring language and culture, noticing verbal and non-verbal cultural behaviours, making connections between home and the target language and culture, and reflecting on the development of a third or intermediate personal position between cultures.
\end{abstract}

Keywords: intercultural language learning, sister school partnership, interaction

How to Cite: Iryanti, H., \& Madya, S. (2018). Investigating intercultural language learning in a sister school partnership between Indonesia and Australia. LingTera, 5(2), 133-143. doi:https://doi.org/10.21831/lt.v5i2.15487

https://doi.org/10.21831/lt.v5i2.15487

\section{INTRODUCTION}

With the rapid growth of information technology, many people are now more globally connected. The possibilities for global communication become greater than ever and therefore, intercultural contact becomes inevitable of this modern life. As people from various origins interact with each other, they need to understand one another's culture to avoid communication breakdown. Having abilities to perform appropriately when interacting with people who are linguistically and culturally different from oneself is very important. These abilities are translated by UNESCO (2013, p. 7) as intercultural competence which is considered to be a requisite response for facilitating interactions among people from various cultures in order to live together in harmony.

The importance of intercultural competence has been recognized in the context of language learning. As highlighted in the Common European Framework of References for Languages (CEFR), in learning a second or foreign language and culture, learners do not simply acquire two distinct ways of acting and communicating, but they become plurilingual and develops interculturality (Council of Europe, 2001, p. 43). The linguistic and cultural competences of each language are modified by knowledge of the other and contribute to intercultural awareness, skills and know-how. They enable individuals to develop a more complex personality and an enhanced capacity for further language learning and greater openness to new cultural experiences.

Culture itself is defined by Lustig, Koester, \& Halualani (2017) in (Chodzkienè, 2014, p. 106) as "a learned set of shared interpretations about beliefs, values, norms and social practices, which affect behaviours of a relatively large group of people." These shared interpretations which are stable over time leading to similar behaviours across similar situations are known as cultural patterns. If the cultural patterns between people are sufficiently different, the symbols used in communication will be interpreted differently, unless people are aware that no 


\section{LingTera, 5 (2), 2018 - 134}

Heni Dwi Iryanti, Suwarsih Madya

common set of behaviour is universally interpreted in the same way. When people from different cultures interact with each other, misunderstanding often occurs because of such differences. One can explain why people from other cultures behave as they do if he or she has a more comprehensive understanding of their culture. In addition, people can also understand why they behave as they do if they are consciously aware of their own culture

There are some models of culture. One of the most well-known models is the iceberg developed by Hall, in which culture can be pictured as an iceberg which is made of visible parts (above the water) and invisible parts (underneath the water line) as illustrated by AFS Intercultural Programs (2010) in Figure 1.

As shown in Figure 1, only a very small portion of the iceberg can be seen above the water line. This top of the iceberg is supported by the much larger part of the iceberg, underneath the water line and therefore invisible. Nevertheless, this lower part of the iceberg is the powerful foundation. Similarly, in culture, there are visible parts such as food, dress, music, and festivals. However, the powerful foundations of culture are more difficult to spot such as the history of people who hold the culture, their norms and values.

The iceberg model implies that the visible parts of culture are just manifestations of its invisible parts. It is difficult at times to understand people with different cultural backgrounds because one may notice the visible parts of "their iceberg" but cannot immediately see the underlying foundations. In intercultural encounters, similarities people might find at first sight usually turn out to be based on completely different assumptions about reality. Learning interculturally is therefore needed in order to become firstly aware of the lower part of one's own iceberg, and to be able to talk about it with others in order to understand each other better and also find common grounds. It is also necessary for students to learn not only about the visible parts of culture but also its hidden aspects by getting actively involved in cultural practices.

Another popular model of culture is suggested by Hosftede (AFS Intercultural Programs, 2010, pp. 2-4) who develops a theory of Cultural Dimensions to explain cultural differences based on his studies involving more than 50 national cultures. His theory offers a framework to examine how cultural values affect behaviours and give clues to why people of a culture might act a certain way. The theory presents six cultural dimensions including Power Distance, Individualism versus Collectivism, Uncertainty Avoidance, Masculinity versus Femininity, Long-Term Orientation, and Indulgence versus Restraint.

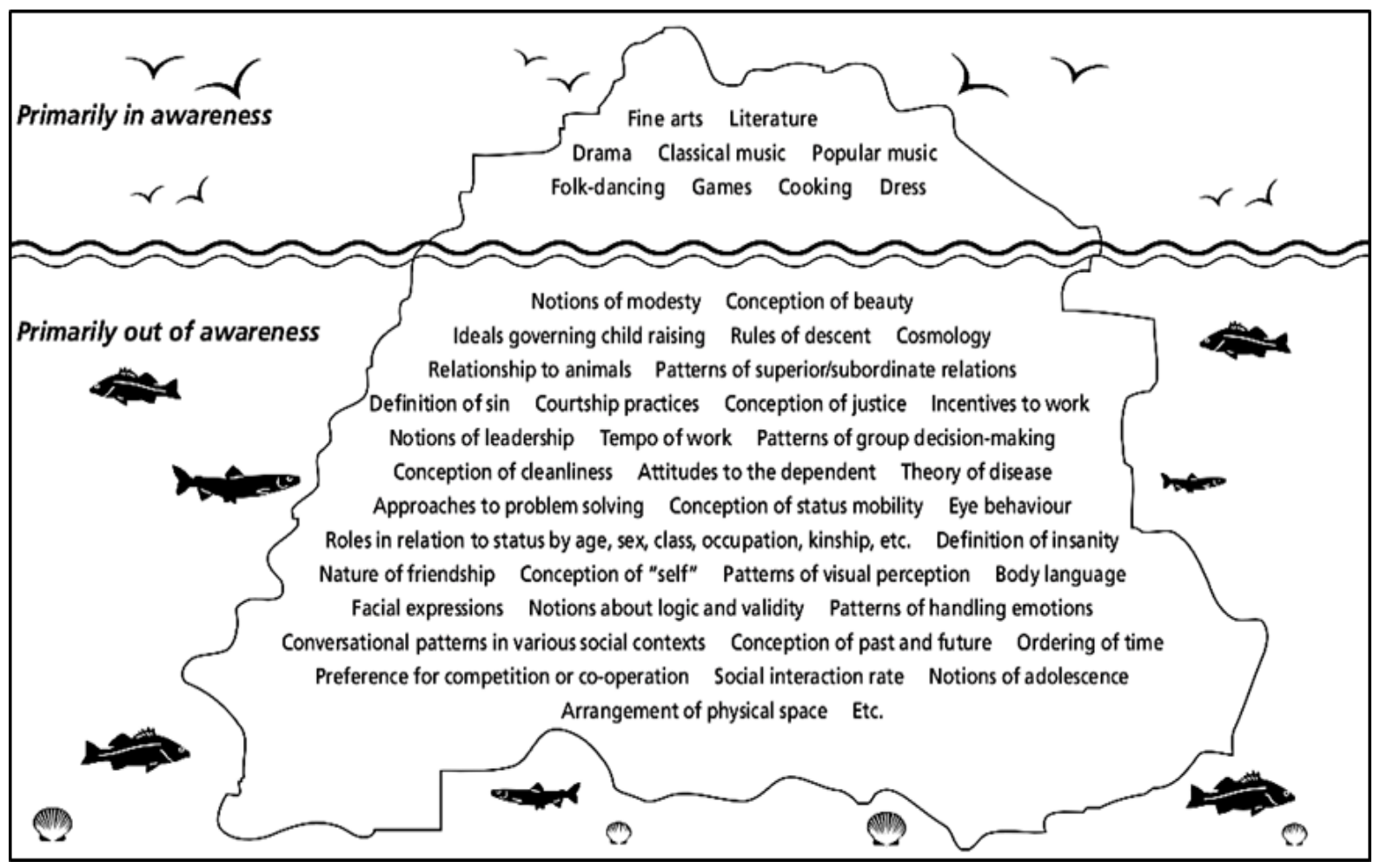

Figure 1. The Iceberg Concept of Culture (AFS Intercultural Programs, 2010) 


\section{LingTera, 5 (2), 2018 - 135}

Heni Dwi Iryanti, Suwarsih Madya

In relation to culture learning in EFL contexts, the Standards for Foreign Language Learning National Standards in Foreign Language Education Project (2006, p. 47) provides a framework for students to integrate the philosophical perspectives, the behavioural practices, and the products both tangible and intangible of a society. This framework is known as the 3P model of culture consisting of Perspectives (what members of a culture think, feel and value), Practices (how members interact with one another) and Products (what members of a group create, share and transmit to the next generation). These aspects are all interconnected as whatever the form of a cultural product, its presence within the culture is required or justified by underlying beliefs and values (perspectives), and the cultural practices involve the use of products. Unlike products, perspectives and practices need to be carefully recognised as they tend to be ingrained in a society.

Integrating culture in language learning is therefore essential as language does not function independently from its cultural contexts of use. In a report on a national survey conducted by Liddicoat, Papademetre, Scarino, \& Kohler (2003), the importance of the interrelationship of languages and cultures is recognized and at the same time, intercultural language learning (IcLL) is also highlighted. Intercultural here is contextually defined as engagement with, or back-andforth movement across languages and cultures. When individuals learn an additional language, it means they generate new possibilities, develop multiple perspectives and create need for mediation between languages and cultures. They may then resist or even challenge cultural practices to which they are exposed in both their first language and the target language.

IcLL begins with the idea that language and culture are fundamentally interrelated concepts. In IcLL, the interrelationship of language and culture is placed at the centre of the learning process. According to Liddicoat et al. (2003, p. 16), IcLL can be understood as moving well beyond a static approach to learning isolated facts about an individual culture and involves the learner in a process of transformation of the self, his/her ability to communicate and to understand communication, and his/her skills for ongoing learning. It is highlighted by Scarino \& Liddicoat $(2009$, p. 21) that the focus of IcLL is to decentre learners from their own culture-based assumptions and to develop an intercultural identity as a result of an engagement with an additional culture. In this context, the borders between self and others are explored, problematized and redrawn.

In developing intercultural language learning experiences, Liddicoat \& Kohler (2012, p. 79) point out that "one's pre-existing culture and identity is an important element as mediation places language students in contact with oppositions between their own cultural positioning and that of the new group with whom they are seeking to engage." However, it is important to note that intercultural language learning is not intended to change students' own cultural identity, but rather to raise their awareness of their cultural identity and broaden their cultural horizons (Madya, 2013, p. 199). Students in this context are expected to decentre from their own cultural identity to see their own positioning from the perspective of another.

Byram (1997) cited in Liddicoat et.al (2003, p.16) develops a model of Intercultural Communicative Competence (ICC) which articulates the relationship of communicative competence and intercultural competence. This model comprises four components as being interdependent and mutually influencing. The components are: (1) Linguistic competence: knowledge of the linguistic code: lexicon, syntax, morphology, semantics, and phonology; (2) Sociolinguistic competence: appropriate selection of language forms for audience and context; (3) Discourse competence: appropriate structuring of the language in the production or reception of texts; and (4) Intercultural competence: knowing how to understand (skills for interpreting and relating information); knowing how to learn/to do (skills for discovering new knowledge and interacting to gain new knowledge); knowing how to be (attitudes involved in relativizing the self and valuing others); and knowing how to commit oneself (education involving the development of critical awareness).

As a basis for understanding the development of intercultural competence, Bennett et al. (1999) in Liddicoat et al. (2003, p. 17) propose a culture-general model for the acquisition of intercultural sensitivity called the Developmental Model of Intercultural Sensitivity (DMIS). This model can be used to explain how learners' abilities operate in an intercultural context, to identify, appreciate, and develop strategies for dealing with cultural differences in communication. 


\section{LingTera, 5 (2), 2018 - 136}

Heni Dwi Iryanti, Suwarsih Madya

This DMIS model consists of two broad stages namely ethnocentrism and ethnorelativism. Both ethnocentrism and ethnorelativism are divided into three stages which are developmentally ordered. The stages of ethnocentrism consist of denial, defence, and minimization, while the stages of ethnorelativism consist of acceptance, adaptation, and integration. Ethnocentrism is defined as a disposition to view one's own cultural point of view as central to reality, while ethnorelativism is the conscious recognition that all behaviour exists within a cultural framework, including one's own. It is argued that ethnocentrism is the starting-point for all intercultural competence and that learner move towards progressively greater levels of ethnorelativism as the result of exposure to and reflection on cultural differences.

There are four stages learners must go through to develop their intercultural competence namely cultural knowledge, cultural awareness, cultural sensitivity, and cultural competence (Sugirin, 2009, p. 4). Cultural knowledge is considered as a prerequisite for intercultural understanding. When learners are familiar with the respected characteristics, values, beliefs and behaviours in the target culture, they will show respect and appreciation. With adequate cultural knowledge, learners will then develop cultural awareness by showing understanding and appreciation accompanied by changes in behaviours and attitudes towards the culture. Proper cultural awareness will naturally produce cultural sensitivity. Learners who have cultural sensitivity will be able to read into situations, contexts and behaviours which are culturally rooted and will be able to react to them appropriately. People will achieve cultural competence only through the possession of adequate cultural knowledge, awareness, and sensitivity. This is the final stage which signifies the actor's ability to work effectively across cultures.

In Indonesia, according to Madya (2013, p. 194), IcLL has become a basic need due to the fact that this country is culturally diverse. It is further argued that intercultural language learning is very much needed to reach mutual understanding among different ethnic groups in Indonesia in order to strengthen national unity. In a more global context, intercultural language learning is also needed when Indonesians come into contact with people from other countries. IcLL is therefore not intended to change students' own cultural identity, but rather to raise their awareness of their own cultural identity and broaden their cultural horizons.

With regard to the implementation of intercultural language learning in Indonesia, Madya (2013, p. 206) proposes a cyclical process modified from (Liddicoat \& Scarino, 2013). It includes four stages namely interaction, noticing, comparing, reflection, and temporary conclusion. When a language learner is involved in interaction with a person from another culture, he/she will notice new input and then compare it to her/his own culture. After that, he/she will critically reflect on the nature of the difference and make a temporary conclusion which can be then revised in the next interaction. This process is cyclical as it facilitates the learner to be a lifelong learner.

There are some studies related to intercultural language learning conducted by scholars abroad. The first is a case study conducted by Moloney (2007) entitled "Intercultural competence in young language learners." This study investigates the characteristics of intercultural competence in 49 Year 6 students in one Australian primary school who have been engaged in an immersion language program for up to eight years, in one of three languages (French, German or Japanese). It also investigates the behaviours and understandings in their four language teachers which may facilitate the development of learners' intercultural competence. It incorporates qualitative data from student focus group interviews, teacher interviews, and classroom observations over a school semester.

The results of the study suggest a number of indicators of the case study students' development in intercultural competence, that is, through understanding of language culture and identity. The students understand the target language itself to be the vehicle of the target culture, and often display metalinguistic curiosity and skills. Some students are able to critically reflect on their (multiple) linguistic and cultural memberships, and to negotiate their identity as a non-native language user. It is also found that teachers provide a model of interculturality to their students. The teachers' interculturality is enacted in their relationships and pedagogical choices, in their design of experiential learning tasks, and their facilitation of linguistic and cultural connections for their students. The study suggests that the nature of the immersion language classroom itself facilitates intercultural competence in students. 


\section{LingTera, 5 (2), 2018 - 137}

Heni Dwi Iryanti, Suwarsih Madya

The second is a study conducted by Ho (2011) entitled "An investigation of intercultural teaching and learning in tertiary EFL classrooms in Vietnam." The study consists of three phases including a curriculum review of culture learning, an analytical study of the perceptions of fourteen Vietnamese EFL teachers and two hundred students on culture in language teaching and learning and an empirical study investigating the effect of adopting an intercultural stance in English speaking lessons over a nine-week period.

Overall, the study provides evidence for the feasibility of intercultural teaching and learning in tertiary EFL classrooms in the Vietnamese context. It also shows that intercultural teaching and learning cultivates learners' affective capacities which are often overlooked in the EFL classroom. This study can inform the work of curriculum designers, education policymakers, EFL teachers and students for the implementation of intercultural language teaching and learning in Vietnam and elsewhere.

Including intercultural in English language learning in Indonesian schools is indeed highly recommended considering that language is closely interrelated with culture. Schools can include it in their regular English lessons to provide students with meaningful learning experiences. In this increasingly interconnected world, it is also very much possible to link with schools overseas by establishing school partnerships in order to bring their students much closer to the target language and culture they learn.

A school partnership or well known as a sister school partnership (SSP) is indeed popular in many countries. In Australia for example, many Australian schools have partnerships across Asia which provides schools with a valuable context to address the Asia priority across learning areas and to deepen knowledge and understanding of the country in which they have international connections (Asia Education Foundation, 2016, p. 4). It is further highlighted that school partnerships in this context are seen as a key vehicle to support students learning a language, to connect with peers globally and to use language in authentic situations.

Establishing a partnership with overseas schools is not an easy task. It needs careful consideration and planning. Before establishing sister school partnerships, schools should know exactly what they want from the partnerships. Schools can start it by imagining in concrete terms how they would like the partnership to be operating one or two years after it has begun, what will be happening and how it will be helping with the teaching and learning. Ideally, a school would gain consensus from its staff and school council for such a partnership before commencing an initial step.

According to the Government of Victoria (2015, p. 16) there are four steps which can be used as a guide for initial thinking and planning in establishing a sister school partnership including assessing the need and plan, finding the right partner, making contact, and establishing the partnership. Lozanski (2008, pp. 8-9) adds that attaining support and commitment from the individuals involving in such as teachers, administrators, students, parents, and community members is integral to success when planning a school partnership. The relationships that evolve among these individuals are at the heart of this partnership.

A study conducted by Brunton (2012) on sister school relationships across Victorian schools show that sister school programs have a significant positive effect on intercultural understanding, global awareness, attitudes and response of students across both primary and secondary schools. This study is commissioned by the Department of Education and Early Childhood Development (DEECD), the Government of Victoria, Australia. It is highlighted in his report entitled "The benefits, impacts and success factors for successful sister school relationships" that this impact is across a range of areas for students, the school, and the school community.

In fact, there are many schools in Indonesia which have partnerships with overseas schools. Both schools generally exchange their school delegation including students, teachers and/or staff members to have overseas learning experiences. As an example, an Indonesian public high school in Yogyakarta has established partnerships with overseas schools for years. Based on our preliminary observation, almost every year, the school hosts a visit from its sister schools and also visit its sister schools abroad. Some partnership programs such as school visits, homestays, and cultural excursions have been regularly carried out.

Our further discussion with the English teacher who is in a charge of this program has raised an important issue to address about how intercultural language learning occurs in such school partnerships. It is true that significant 


\section{LingTera, 5 (2), 2018 - 138}

Heni Dwi Iryanti, Suwarsih Madya

amounts of time, energy and money have been spent to operate a sister schools partnership, and yet there has been no investigation conducted in Indonesia to research intercultural language learning within this partnership.

For Indonesia, where English is learnt as a Foreign Language (EFL), sister school partnerships can be utilised as a powerful mechanism to provide Indonesian students with authentic learning resources which allow them to come into contact with their counterparts from other countries. As they engaged with their foreign counterparts in partnership programs, they develop their greater awareness of and positive attitudes to cultural differences in global contexts. Against this background, this study is conducted to reveal how intercultural language learning occurs within a sister school partnership and to describe student behaviours which are perceived to be indicative of intercultural language learning.

\section{METHOD}

This research is a case study which is defined by Yin (2014, p. 16) as an empirical inquiry that investigates a contemporary phenomenon in depth and within its real-world context. It was aimed at investigating an existing phenomenon of intercultural language learning within a sister school partnership as a specific bounded case. It employed an ethnographic approach suggested by Roberts, Byram, \& Barro (2001, p. 3) by going out into the field to look very closely at the phenomenon in a natural setting through observations and dialogues.

In this context, the investigation was focused on the phenomenon where the student were studying the target language and culture within the partnership programs both in their home country and the target country. It captured their real life interactions in some different places such as at school, home, cultural sites and other public places. The implementation of the sister school partnership in its natural setting was contextualised and thoroughly investigated to reveal how intercultural language learning occurred within. The students' understandings and behaviours in intercultural interactions which were perceived to be indicative of intercultural language learning were also further examined and described. Through the use of multiple data sources in the target context, this research captured the full complexity and uniqueness of the case in order to provide a richly detailed description of the situation.
This research was conducted in an Indonesian public high school in Yogyakarta which has a strong academic reputation (will hereafter be written as 'the Indonesian school'). This school has a global orientation as its policymaker consistently benchmarks their systems against international standards. As a part of its internalization programs, the school has established some partnerships with overseas schools for years to conduct collaboration programs including with an Australian school.

Considering that Australia is one of English speaking countries, the investigation in this study was focused on the partnership between the Indonesian school and its Australian school partner. Almost every year, the Indonesian school hosts a visit from its sister schools. It also visits its Australian school partner, usually as a biennial visit. There are a number of partnership programs carried out during in-country visits such as school visits, homestays, guided tours and cultural excursions. These programs allow the students to get engaged with their Australian counterparts in intercultural interactions using the target language (English).

In selecting the participants of the research, we used purposeful random sampling as suggested by Lodico, Spaulding, \& Voegtle (2010, p. 135) to obtain a sample consisting individuals who were best able to provide the richest and most detailed information related to the focus of the study. These individuals were randomly sampled from the group who were directly involved in the partnership programs. They consisted of 10 Indonesian students from grade 10-11. Most of them speak Indonesian and Javanese. They had an intermediate level of proficiency in English. They mostly come from upper middle class families whose parents are teachers, lecturers, hotel managers, school founders, entrepreneurs, and other professionals. Their family backgrounds may contribute to their learning motivation and involvement in the partnership programs, and therefore can be used as additional information to help contextualise their behaviours in intercultural interactions.

Those 10 students were key participants for this study as they were directly involved in the sister school partnership program at that school. Eight of them joined a visit program to their Australian sister school in November 2016 for two weeks and also became host families when hosting a visit from their Australian sister school in March 2017. Meanwhile, 2 remaining students did not join a visit to their Australian sister school 


\section{LingTera, 5 (2), 2018 - 139}

Heni Dwi Iryanti, Suwarsih Madya

but they volunteered themselves to be host families when hosting a visit from their Australian sister school. The English teacher who was in charge of the program, together with some other teachers were also involved as informants in this study.

This study also involved a group of 4 Australian teachers and 10 students year 10-11 as partners in intercultural interactions. These 10 Australian students were the homestay partners with whom the Indonesian students mostly interacted during the reciprocal visits. These 10 students were also the host families when the Indonesian students conducted a visit program in Australia.

Regarding the research procedure, this study followed steps in designing qualitative research suggested by Lodico et al. (2010, pp. 160-165). The steps included identifying a research focus, conducting a review of literature, defining the role of the researcher, writing qualitative research questions, selecting participants, collecting the data, analysing and interpreting the data, and disseminating results.

This ethnographic case study used mostly qualitative techniques and involved more researcher participation. Some qualitative techniques including observations, in-depth interviews, document analyses, and focus group discussions (FGD) were used to collect the data for about six months. The data collection was focused on interactions occurring among the research participants including their behaviours, reactions, responses, feelings, opinions, expectations, and preferences related to the case. The data collected were therefore in the form of student FGD transcripts, teacher interview transcripts, vignettes, and also photographs.

The collected data of this research were then analysed qualitatively following the six steps in analysing qualitative data proposed by (Lodico et al. (2010, p. 180). The steps included preparing and organizing the data, reviewing and exploring the data, coding data into categories, constructing thick descriptions of people, places, and activities, building themes, reporting and interpreting data

In regard to the quality of this study, we used criteria suggested by Lodico et al. (2010, pp. 169-174) to ensure the validity and reliability including four major areas namely credibility, dependability, transferability, and catalytic authenticity. Credibility was examined through conducting multiple in-depth interviews with the participants, and these interviews probed their experiences in depth, maintaining our involvement in the group activities both as a complete observer and a participant observer in order to make sure that the participants behaved, reacted and responded naturally, and ensuring that the procedures used in this study promoted deep reflection and analysis of the meaning of the experiences and that the analysis of the findings ended with a neutral optimistic tone.

Dependability was fulfilled by presenting the research methodology used in this study thoroughly in order that the procedures and processes used to collect and interpret the data could be obviously tracked. Transferability was assessed by looking at the richness of the descriptions included in the study as well as the amount of detail provided about the context within which the study occurred. Although the finding of qualitative research could not be generalizable to all other settings, the lessons learned in this particular setting could be a valuable addition to knowledge in this area.

Catalytic authenticity was assessed by asking whether this research had stimulated change for the better in ways that were truly desired by the study participants. Evidence, therefore, included descriptions of how the research participants collaborated with us in determining what changes needed to occur and in planning any further actions.

To enhance the trustworthiness of this study, we used the triangulation technique suggested by Stake (2005, p. 454) as a process of using multiple perceptions to clarity meaning and verifying the repeatability of all observation or interpretation. It was addressed by comparing different sources of data and perspectives of different participants. In confirming evidence of this study, I examined the data from different techniques (observations, in-depth interviews and FGD) and from different perspectives (the students, the teachers, the school principal, and the public relations officer in the Indonesian school and their Australian counterparts).

\section{FINDINGS AND DISCUSSIONS}

The findings of this study were synthesized from a number data collected for about six months including observations, indepth interviews, document analyses, and student focus group discussions (FGD). The discussions of findings comprise two parts including contextualisation of the sister school partnership and intercultural language learning within this partnership. 


\section{Contextualisation of the Sister School Partnership}

In regard to the phases of relationship building, it was found that the sister school partnership between the Indonesian school and its Australian school partner was initiated in 1994 by a senior English teacher in the Indonesian school through a personal network with an Australian teacher. As a part of its internationalization programs at that time, the school established the partnership with an Australian school based on mutual respect, trust, and understanding. This partnership was then legalised in a written agreement or a Memorandum of Understanding (MoU).

Over 20 years, the sister school partnership has been well cultivated. The Indonesian school has successfully run a number of partnership programs with its Australian sister school, mostly in the form of regular reciprocal visits which involves active engagement from both schools. Support and commitment from individuals involved in both schools has kept the partnership alive. This partnership yields some positive learning outcomes including personal growth, language learning, cultural knowledge and intercultural development.

In practice, the sister school partnership requires support and commitment from the individuals involved in, such as teachers, administrators, students and also their parents. The relationships that evolve among these individuals are at the heart of the sister school partnerships. When these individuals are involved in sister school activities in global contexts, they develop their personal qualities. This personal growth generally manifest with respect to taking responsibility for self, coping with being outside their familiar and supportive home environment and also getting on with other people whose norms and cultural values of behaviours are different from theirs.

The opportunity for real life interactions in this sister school partnership caters for authentic userfriendly language learning (English for the Indonesian students and Indonesian for the Australian students). In this context, the teacher moves on from being over dependent on a set of teaching and learning practices in regular classes to more current and authentic language collaboration with the target language community. As previously discussed, the reciprocal visits always include residence with a host family in which each student (both Indonesian and Australian) is placed in each homestay to promote immersion in the host language. This homestay experience allows the students to naturally acquire and utilise the target language in authentic contexts. Some emerging technologies are also used to engage and challenge their language learning. With these resources, learning can be more authentic, creative, and collaborative.

As the individuals involved in this partnership come into contact with their Australian counterparts, they naturally develop a sense of culture they are exposed to. In exchange visits, the students can build their cultural understanding and sensitivity by exploring places and events that reflect cultural identities of Indonesian and Australia. They gain cultural knowledge not only about Indonesian and Australian traditional and historical cultures but also its modern society with diverse beliefs, perspectives, and values. This cultural knowledge can be reflected in their perception of similarities and differences between their own culture and the target culture they learn. In this case, they do not simply know factual information about culture, but rather understand how to engage with it.

The sister school programs especially reciprocal visits have a significant positive effect on intercultural development of the individuals involved in. Through exposure to and active engagement with languages and cultures, the students recognise, compare and reflect on their home culture as much as on their target culture. They can consciously learn to understand their own culture in relation to others. Hence, they become more aware of their own cultural difference and understand how to engage with it. This intercultural development is an ongoing process, and therefore requires continuous intercultural learning through new experiences and critical reflection.

\section{Intercultural Language Learning within the Sister School Partnership}

A number of indicators of intercultural language learning were revealed in the student behaviours within four broad areas as presented in Table 1. They included exploring language and culture in authentic situations, noticing verbal and non-verbal behaviours in the target language and culture interactions, making connections between home and the target language and culture, and reflecting on the development of a 'third' or intermediate personal position between cultures. These areas were perceived as authentic language experiences occurring within the part- 


\section{LingTera, 5 (2), 2018 - 141}

Heni Dwi Iryanti, Suwarsih Madya

nership programs such as in school visits, cultural excursions and homestays which contributed to intercultural development towards a more ethnorelative world-view.

Intercultural language learning in this context began with exploring language and culture in authentic situations. In this stage, the students from both countries experienced real life interactions with the members of the target language and culture by getting actively involved in the reciprocal visits. This allowed them to naturally acquire language and culture through some partnership activities such as school visits, homestays, guided tours and cultural excursions. This language and cultural exploration enabled the students to develop a much better understanding of their own language and culture and learn about the target language and culture.

As the individuals involved in this partnership came into contact with their Australian counterparts, they naturally developed a sense of culture they were exposed to. In exchange visits, the students built their cultural understanding and sensitivity by exploring places and events reflecting cultural identities of Indonesian and Australia. They gained cultural knowledge not only about Indonesian and Australian traditional and historical cultures but also its modern society with diverse beliefs, perspectives, and values. This cultural knowledge was reflected in their perception of similarities and differences between their own culture and the target culture they learned. In this case, they did not simply know factual information about culture, but rather understood how to engage with it.

The next stage was noticing verbal and non-verbal behaviours in the target language and culture interactions. Here the students started recognising particular features of verbal and nonverbal behaviours practised by the members of the target language and culture. This noticing allowed them to identify some distinctive elements of the target language used naturally in verbal communication, such as its accent, pronunciation, and vocabulary use. They also became more aware of the underlying cultural values and understood the connection between the functions and interpretations of verbal and non-verbal behaviours.

After noticing, the students made connections between their home and the target language and culture. In this stage, they first compared their home and the target language and culture to identify their similarities and differences. In making connections, the students then related their existing knowledge about language and culture to new input they got from their interaction with the members of the target language community. They used their new understanding to compare their home language and culture with the target language and culture in order to draw connections. By making connections, the students were able to develop an understanding of why there were differences in the way people behaved and communicated.

Table 1. A mapping of four areas of students' language experiences and student behaviours investigated within the sister school partnership

\begin{tabular}{|c|c|c|}
\hline No. & Language experiences & Student behaviours \\
\hline 1. & $\begin{array}{l}\text { Exploring language and culture in authentic } \\
\text { situations (ELCA) }\end{array}$ & $\begin{array}{l}\text { Students use English to communicate in real life } \\
\text { interactions (ELCA 1) } \\
\text { Students expose themselves to the target culture } \\
\text { 'Australian' (ELCA 2) } \\
\text { Students expose their Australian fellows to their home } \\
\text { 'Indonesian' culture (ELCA 3) }\end{array}$ \\
\hline 2. & $\begin{array}{l}\text { Noticing verbal and non-verbal behaviours in } \\
\text { the target language and culture interactions } \\
\text { (NBLC) }\end{array}$ & $\begin{array}{l}\text { Students notice features of verbal behaviours practised } \\
\text { by Australians (NLBC } 1 \text { ) } \\
\text { Students notice features of non-verbal behaviours } \\
\text { practised by Australians (NLBC 2) }\end{array}$ \\
\hline 3. & $\begin{array}{l}\text { Making connections between Indonesian } \\
\text { language and culture and the target language } \\
\text { and culture (MCLC) }\end{array}$ & $\begin{array}{l}\text { The students compare their home language } \\
\text { (Indonesian) with the target language (English) } \\
\text { (MCLC 1) } \\
\text { The students compare their home culture (Indonesia) } \\
\text { and the target culture (Australia) (MCLC 2) }\end{array}$ \\
\hline 4. & $\begin{array}{l}\text { Reflecting on the development of a 'third' or } \\
\text { intermediate personal position between } \\
\text { cultures (RDPC) }\end{array}$ & $\begin{array}{l}\text { Students promote their cultural identity (RDPC 1) } \\
\text { Students show ethnorelative outlook in self (RDPC 2) } \\
\text { Students modify their behaviours (if needed) in } \\
\text { intercultural interactions (RDPC 3) }\end{array}$ \\
\hline
\end{tabular}


The last stage was reflecting on the development of a 'third' or intermediate personal position between cultures. In this stage, they developed many positive ethnorelative outlooks in self as the result of exposure to and reflection on cultural differences. They created something autonomous in-between which allowed for conscious positioning of self when confronting cultural difference. In this way, they were able to decentre from their own cultural identity to see their own positioning from the perspective of others. This process did not make them change their own cultural identity, but rather, raised their awareness of their cultural identity and broadened their cultural horizons. They were able to accept the existence of different cultural contexts, usually manifested by a respect for difference. In intercultural interactions, they developed ways of modifying behaviours (if needed) by shifting their cultural frame of reference in order to be intercultural.

\section{CONCLUSIONS}

The research findings and discussions show that intercultural language learning occurs within the sister school partnership through experiences which engage the students and teachers in interaction, observation, and reflection with the target language and culture community. The reciprocal visits as the common element in the partnership programs conducted by the Indonesian school with its Australian sister school provides them with opportunities for realworld language use and cultural exploration in global contexts. As they interact with their counterparts from different countries, they naturally develop an intercultural sensitivity.

There are several indicators of intercultural language learning revealed in the student and teacher behaviours within four authentic language experiences. They include exploring language and culture in authentic situations, noticing verbal and non-verbal behaviours in the target language and culture interactions, making connections between home and the target language and culture, and reflecting on the development of a 'third' or intermediate personal position between cultures. These areas are perceived to be an ongoing process of intercultural language learning with no final-end point.

The four areas previously mentioned contribute positively to intercultural development towards a more ethnorelative world-view. In this context, students completely realise that they are non-members of the target language community.
They do not change their identity to be like them, but they develop a third or intermediate personal position between cultures as the target language users. This position is independent of both their native language and culture and the target language and culture. As this intercultural development is considered an ongoing process, the students do not stop their continuous intercultural language learning through new experiences and critical reflection.

\section{REFERENCES}

AFS Intercultural Programs. (2010). Hofstede's cultural dimension.

Asia Education Foundation. (2016). International school partnerships toolkit. Victoria: The University of Melbourne.

Brunton, C. (2012). The benefits, impacts and success factors for successful sister school relationships. Melbourne Vic.

Byram, M. (1997). Teaching and assessing intercultural communicative competence. Clevedon: Multilingual Matters.

Chodzkiene, L. (2014). What every student should know about intercultural communication. Vilnius University.

Council of Europe. (2001). Common European framework of reference for languages: Learning, teaching, assessment. Cambridge, MA: Cambridge University Press.

Government of Victoria. (2015). Overseas learning experiences for students: a resource for schools. Melbourne, Vic.: The International Education Division, Department of Education and Early Childhood Development.

Ho, S. T. K. (2011). An investigation of intercultural teaching and learning in tertiary EFL classrooms in Vietnam. Victoria University of Wellington. Retrieved from http://researcharchive.vuw.ac.nz/handle/1 0063/4447

Liddicoat, A. J., \& Kohler, M. (2012). Teaching Asian languages from an intercultural perspective: Building bridges for and with students of Indonesian. In Bridging Transcultural Divides: Asian Language and Culture in Global Higher Education (pp. 73-99). Adelaide: University of Adelaide Press.

Liddicoat, A. J., Papademetre, L., Scarino, A., \& 


$$
\text { LingTera, } 5 \text { (2), } 2018 \text { - } 143
$$

Heni Dwi Iryanti, Suwarsih Madya

Kohler, M. (2003). Report on intercultural language learning. Canberra.

Liddicoat, A. J., \& Scarino, A. (2013). Language teaching and learning as an intercultural endeavor. In Intercultural Language Teaching and Learning (pp. 47-62). Oxford: Blackwell Publishing Ltd. https://doi.org/10.1002/9781118482070.c h4

Lodico, M. G., Spaulding, D. T., \& Voegtle, K. H. (2010). Methods in educational research : from theory to practice. JosseyBass.

Lozanski, L. (2008). A guide to international school partnerships. Alberta Education.

Lustig, M. W., Koester, J., \& Halualani, R. (2017). Intercultural competence: interpersonal communication across cultures. Pearson.

Madya, S. (2013). Metodologi pengajaran bahasa dari era prametode sampai era pascametode. Yogyakarta: UNY Press.

Moloney, R. A. (2007). Intercultural competence in young language learners: A case study.
University of Sydney.

National Standards in Foreign Language Education Project. (2006). Standards for foreign language learning in the 21st century. Allen Press.

Roberts, C., Byram, M., \& Barro, A. (2001). Language learners as ethnographers. Clevedon: Multilingual Matters.

Scarino, A., \& Liddicoat, A. (2009). Teaching and learning languages: A guide. Curriculum Corporation Melbourne.

Stake, R. E. (2005). Qualitative case studies. In N. K. Denzin \& Y. S. Lincoln (Eds.), The Sage Handbook of Qualitative Research (pp. 443-466). Thousands Oaks: SAGE Publications.

Sugirin, S. (2009). Cross-cultural understanding: What every EFL teacher should know. Purworejo.

UNESCO. (2013). Intercultural competences: Conceptual and operational framework. Paris: UNESCO.

Yin, R. K. 1941-. (2014). Case study research : design and methods. Sage Publ. 